Photomosaics and Event Evidence from the Frazier Mountain Paleoseismic Site, Trench 1, Cuts 5-24, San Andreas Fault Zone, Southern California (2010-2012)

By Katherine M. Scharer, Tom E. Fumal, Ray J. Weldon, II, Ashley R. Streig

Pamphlet to accompany

Open-File Report 2015-1147

U.S. Department of the Interior

U.S. Geological Survey 


\section{U.S. Department of the Interior \\ SALLY JEWELL, Secretary}

U.S. Geological Survey
Suzette M. Kimball, Acting Director

U.S. Geological Survey, Reston, Virginia: 2015

For more information on the USGS-the Federal source for science about the Earth, its natural and living resources, natural hazards, and the environment-visit http://www.usgs.gov/ or call 1-888-ASK-USGS (1-888-275-8747).

For an overview of USGS information products, including maps, imagery, and publications, visit http://www.usgs.gov/pubprod/.

To order USGS information products, visit http://store.usgs.gov/.

Any use of trade, firm, or product names is for descriptive purposes only and does not imply endorsement by the U.S. Government.

Although this information product, for the most part, is in the public domain, it also may contain copyrighted materials as noted in the text. Permission to reproduce copyrighted items must be secured from the copyright owner.

Suggested citation:

Scharer, K.M., Fumal, T.E., Weldon, R.J., II, Streig, A.R., 2015, Photomosaics and event evidence from the Frazier Mountain paleoseismic site, trench 1, cuts 5-24, San Andreas Fault Zone, southern California (2010-2012): U.S. Geological Survey Open-File Report 2015-1147, 25 p., 3 sheets, http://dx.doi.org/10.3133/ofr20151147. 


\section{Contents}

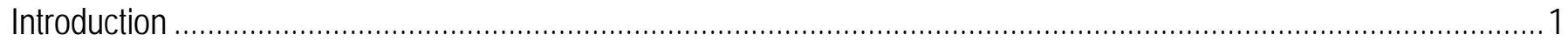

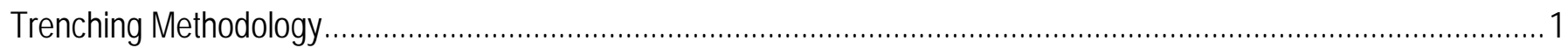

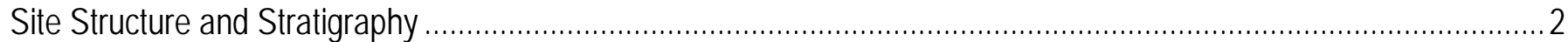

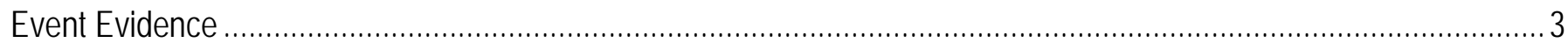

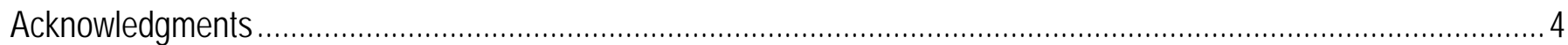

References Cited

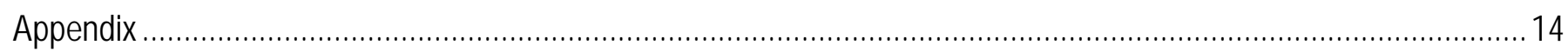

\section{Figures}

1. Location and tectonic setting of Frazier Mountain paleoseismic site.....................................................

2. Trench 1 excavations within the geomorphic depression at Frazier Mountain paleoseismic site .............7

3. Stratigraphic column and unit descriptions of sediments exposed in trench 1 at Frazier Mountain

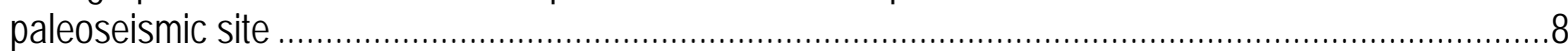

4. Composite of simplified trench 1 logs, lower section, Frazier Mountain paleoseismic site .....................11

5. Plot showing event quality for each stratigraphic unit in trench 1 cuts $5-24 \ldots \ldots \ldots \ldots \ldots \ldots \ldots \ldots \ldots \ldots \ldots \ldots . . . .13$

\section{Tables}

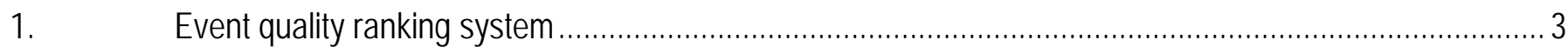

A1. Location and quality of event evidence from the Frazier Mountain paleoseismic site, trench 1, cuts 524, San Andreas Fault, southern California (2010-2012) ................................................................. 14 


\title{
Photomosaics and Event Evidence from the Frazier Mountain Paleoseismic Site, Trench 1, Cuts 5-24, San Andreas Fault Zone, Southern California (2010-2012)
}

\author{
By Katherine M. Scharer, ${ }^{1}$ Tom E. Fumal, ${ }^{1}$ Ray J. Weldon, II, ${ }^{2}$ Ashley R. Streig${ }^{2}$
}

\section{Introduction}

The Frazier Mountain paleoseismic site is located within the northern Big Bend of the southern San Andreas Fault (lat $34.8122^{\circ}$ N., lon $118.9034^{\circ} \mathrm{W}$.), in a small structural basin formed by the fault (fig. 1). The site has been the focus of over a decade of paleoseismic study due to high stratigraphic resolution and abundant dateable material. Trench 1 (T1) was initially excavated as a 50-m long, faultperpendicular trench crossing the northern half of the basin (Lindvall and others, 2002; Scharer and others, 2014a). Owing to the importance of a high-resolution trench site at this location on a 200-km length of the fault with no other long paleoseismic records, later work progressively lengthened and deepened T1 in a series of excavations, or cuts, that enlarged the original excavation. Scharer and others (2014a) provide the photomosaics and event evidence for the first four cuts, which largely show the upper section of the site, represented by alluvial deposits that date from about A.D. 1500 to present. Scharer and others (2014b) discuss the earthquake evidence and dating at the site within the context of prehistoric rupture lengths and magnitudes on the southern San Andreas Fault. Here we present the photomosaics and event evidence for a series of cuts from the lower section, covering sediments that were deposited from about A.D. 500 to 1500 (fig. 2).

\section{Trenching Methodology}

To access the lower section at the Frazier Mountain paleoseismic site, we removed the upper $~ 2$ $\mathrm{m}$ from the area around T1, which had been extensively studied by Scharer and others (2014a,b). Below this bench a high water table required that the deeper excavations be cut with sloping walls. Each cut is identified by the trench name (T1), the side of the trench exposed (east [E] or west [W]), and numbered sequentially away from the original trench excavation. For example, T1E13 is a cut on the east side of T1, and is the 13th cut. We present a total of 11 cuts, eight from the east side (T1E5, T1E7, T1E8, T1E11, T1E13, T1E20, T1E21, and T1E23) and three from the west side (T1W18, T1W22, and T1W24) (fig. 2). The cuts not presented here (such as T1E6, T1E9) were typically only a few centimeters away from the cuts shown here and (or) limited in extent, so they did not provide additional evidence. There are fewer excavations on the west side of $\mathrm{T} 1$ because the groundwater flow is from the west, which made the west wall persistently wet and difficult to study.

The cuts were made by an excavator or by manually digging back a preexisting wall. The distance between cuts is variable, from $20 \mathrm{~cm}$ to several meters (fig. 2). Each wall was scraped smooth,

\footnotetext{
${ }^{1}$ U.S. Geological Survey

${ }^{2}$ University of Oregon
} 
affixed with a local grid, and photographed. The vertical strings on the grids were placed $\sim 1 \mathrm{~m}$ apart although they diverge if the wall is curved. The horizontal strings were established $1 \mathrm{~m}$ apart in a vertical plane, and then projected onto the sloping trench walls, which dip 40-60 (fig. 2C). As a consequence, the distance between the horizontal strings on the wall is $\sim 1.1-1.5 \mathrm{~m}$. The grid was surveyed with a total station so the relative position of each cut is known to within $\sim 5 \mathrm{~cm}$ in the local reference frame. Each grid rectangle was photographed and the exposed stratigraphy was logged directly onto a photograph in the field at a scale of $\sim 1: 5$. To generate the photomosaics, we projected the total station grid onto a plane parallel to the average orientation of the cut. Each photo was rubber sheeted to this grid and the line work was transferred from the detailed field logs. The three sheets that accompany this text are organized so that the trench cuts are shown in succession from the eastern-most (starting with T1E23 on Sheet 1) to the western-most (ending with T1W24 on Sheet 3).

\section{Site Structure and Stratigraphy}

The Frazier Mountain paleoseismic site sits within a small basin on the northern flank of Frazier Mountain (Scharer and others, 2014a,b). T1 is located at the break in slope within the basin, between a broad, southeast dipping alluvial fan and a flat basin floor approximately $170 \mathrm{~m}$ long by $70 \mathrm{~m}$ wide (fig. $1 B, 2 A)$. The alluvial fan sources Precambrian gneisses and Pliocene sedimentary rocks of the Hungry Valley Formation (Crowell, 2003). Recent faulting in the upper section is dominated by a right-step from the main fault zone to displacements along a set of faults to the north (fig. $2 B$ ). This releasing-bend structure produces a transtensional basin that has been repeatedly deepened by faulting and filled by sediments since at least A.D. 1200 (Scharer and others, 2014b). A persistent observation of the lower section is that the units generally thicken to the west, reaching maximum thicknesses (a) at the transition from the gently sloping fan to the flat basin and (b) where accommodation space is created by transtensional faulting. As with the upper section, stratigraphic packages in the lower section generally thin towards to the northern and southern margins of the trench (in other words, outside of the zone of active faulting).

We present a stratigraphic section of the deposits observed in T1 (fig. 3); the lower section is loosely defined as units 65 through 35. The base of the section (unit 65) is sand with cobbles that is overlain by a 1-m-thick, coarse-sand-and-silt package (units 64 through 59). From units 59 through 39, the section is dominated by silt layers, with alternating clay and sand units, and some thin, organic-rich layers. The section generally coarsens upward above unit 39. Colored lines on the trench logs (fig. 4) highlight units that are laterally extensive, such as white clay layers (units 43, 45, and 51), organic-rich layers (units 39, 48, 53), and clay layers (units 49, 54, 58). Dating of this section with radiocarbon and luminescence techniques will be addressed in a separate report.

Faults in the lower section are concentrated in two fault zones about $12 \mathrm{~m}$ apart (fig. 4). The fault dips shown in the trench logs are apparent, because most of the walls are sloping. In this view, the main fault zone dips steeply to the south and the northern fault zone dips to the north (fig. 4). Following deposition of the lower section, both fault zones have been partially overprinted by faulting from at least five earthquakes. When the younger folding is removed, the lowest faults in the northern fault zone are, in places, restored to vertical or southward dipping, resulting in asymmetric faulting consistent with graben structures seen in transtensional basins. Overall, the pattern of complex faulting is similar to negative flower structures documented in analog models (Wu and others, 2009). The deep excavations

revealed some low-angle faults that are locally parallel to bedding. Low-angle faults cut younger highangle faults, or are connected with subvertical faults that extend to higher levels (as high as unit 25 in T1E23, for example), thus we interpret that the formation of these low-angle faults postdates the lower section and the deformation of interest in this report. 


\section{Event Evidence}

We follow the approach of Scharer and others (2007) in which deformation in the form of faulting, fissures, colluvial wedges, and fanning dips that characterize growth strata are labeled "event evidence" and ranked based on the quality of the deformation (table 1; Appendix). The quality of each observation is based on a scale of 0 to 5; higher values reflect stronger evidence that (a) the deformation was produced by a distinct earthquake and (b) the exact stratigraphic horizon (and thus age of the deformation) is identifiable. The event quality ranking system is similar to the system used in Scharer and others (2014a), but additional description is added for ranks of 1 and 2 related to folding evidence. In the original system, all folding evidence was given a rank of 3 or higher, principally because folding events in the upper section were generally more substantial, often producing over $50 \mathrm{~cm}$ of vertical deformation across the length of T1. In the lower section, however, the folding evidence for some events is subtler, and could not always be confidently distinguished from nontectonic depositional patterns at the site.

Table 1. Event quality ranking system.

\begin{tabular}{cc}
\hline Quality & Description \\
\hline 0 & Fault tip where upper termination not distinct due to unclear stratigraphy \\
1 & Fault with minor offset. Minor and gradual thickness changes that could simply reflect depositional gradients \\
& rather than filling of earthquake-produced depression
\end{tabular}

We summarize event evidence at each stratigraphic unit by plotting the range of quality of observations (ranks 0-5), the total number of event indicators, and the sum of quality of evidence for the exposures in this report (fig. 5). Most of the deformation is concentrated in a few layers (units 46, 49, 52, 54, and 55). We qualify each earthquake horizon on the basis of consideration of this plot, following Scharer and others (2007), as very unlikely, possible, probable, likely, or very likely. Evidence for deformation in units 43, 50, 51, and 57 is very weak or limited, so we do not identify these as earthquake horizons. Evidence for deformation in unit 46 is complex because it is not clear if the event indicators towards the top of the unit (horizon 46.1 in Appendix) are evidence for continued filling of a sag pond that formed during an earlier earthquake in unit 46 (horizon 46.2 in Appendix) or are representative of a separate earthquake. However, the range of evidence indicates at least one earthquake occurred during the deposition of unit 46. The deformation associated with unit 52 is often overprinted by younger deformation, so the overall quality is low $(\leq 2)$, but the total number of observations is similar to other horizons, increasing the likelihood that the deformation is the product of an earthquake. There is only one exposure with event evidence for unit 55. The deformation is significant (3), and appears to be separate from subsequent faulting during deposition of unit 54. In contrast, although the deformation at unit 57 is also seen in only one location, the event quality is low (1). Consequently, we consider it very likely that large earthquakes occurred during deposition units 46, 49, and 54, likely that an earthquake occurred during the deposition of unit 52, and probable that a large earthquake occurred during deposition of 55. 


\section{Acknowledgments}

This work was sponsored by internal and external funds of the Earthquake Hazard Reduction Program of the U.S. Geological Survey (USGS) (05HQGR0071, 09AP00012, 11AP201223) and grants from the National Science Foundation (NSF) (0838294) and the Southern California Earthquake Center (SCEC) to Appalachian State University and the University of Oregon. SCEC is funded by NSF Cooperative Agreement EAR-1033462 and USGS Cooperative Agreement G12AC20038. The SCEC contribution number for this paper is 1902. The fieldwork could not have been completed without the assistance of a number of students and colleagues, including Brian Gibson, Maria Ortuno, Bevin Bailey, Judy Zachariesen, Carl Swanson, Nick Weldon, Nyle Weldon, Rachel Lippoldt, and Andy Jerrett. Reviews by Suzanne Hecker and Scott Bennett helped to improve the document.

\section{References Cited}

Bevis, M., Hudnut, K., Sanchez, R., Toth, C., Grejner-Brzezinska, D., Kendrick, E., Caccasmise, D., Raleigh, D., Zhou, H., Shan, S., Shindle, W., Yong, A., Harvery, J., Borsa, A., Ayoub, F., Shrestha, R., Carter, B., Sartori, M., Phillips, D., and Coloma, F., 2005, The B4 project—Scanning the San Andreas and San Jacinto fault zones: American Geophysical Union, Fall Meeting 2005 Abstracts, abstract no. H34B-01.

Crowell, J.C., 2003, Tectonics of Ridge Basin region, southern California, in Crowell, J.C., ed., Evolution of Ridge Basin, southern California—An interplay of sedimentation and tectonics: Geologic Society of America Special Paper 367, p. 157-203.

Lindvall, S.C., Rockwell, T.K., Dawson, T.E., Helms, J.G., and Bowman, K.W., 2002, Evidence for two surface ruptures in the past 500 years on the San Andreas Fault at Frazier Mountain, California: Bulletin of the Seismological Society of America, v. 92, no. 7, p. 2689-2703.

Scharer, K.M., Weldon, R.J., II, Fumal, T.E., and Biasi, G.P., 2007, Paleoearthquakes on the southern San Andreas Fault, Wrightwood, California, 3000 to 1500 B.C.-A new method for evaluating paleoseismic evidence and earthquake horizons: Bulletin of the Seismological Society of America, v. 97, no. 4, p. 1054-1093.

Scharer, K.M., Fumal, T.E., Weldon, R.J., II, Streig, A.R., 2014a, Photomosaics and event evidence from the Frazier Mountain paleoseismic site, Trench 1, Cuts 1-4, San Andreas Fault Zone, southern California (2007-2009): U.S. Geological Survey Open-File Report 2014-1002, pamphlet 23 p., 4 sheets, various scales, http://dx.doi.org/10.3133/ofr20141002.

Scharer, K., Weldon, R., II, Streig, A., Fumal, T., 2014b, Paleoearthquakes at Frazier Mountain, California delimit extent and frequency of past San Andreas Fault ruptures along 1857 trace: Geophysical Research Letters, v. 41, no. 13, p. 4527-4534.

Wu, J.E., McClay, K., Whitehouse, P., Dooley, T., 2009, 4D analogue modelling of transtensional pullapart basins: Marine and Petroleum Geology, v. 26, no. 8, p. 1608-1623. 


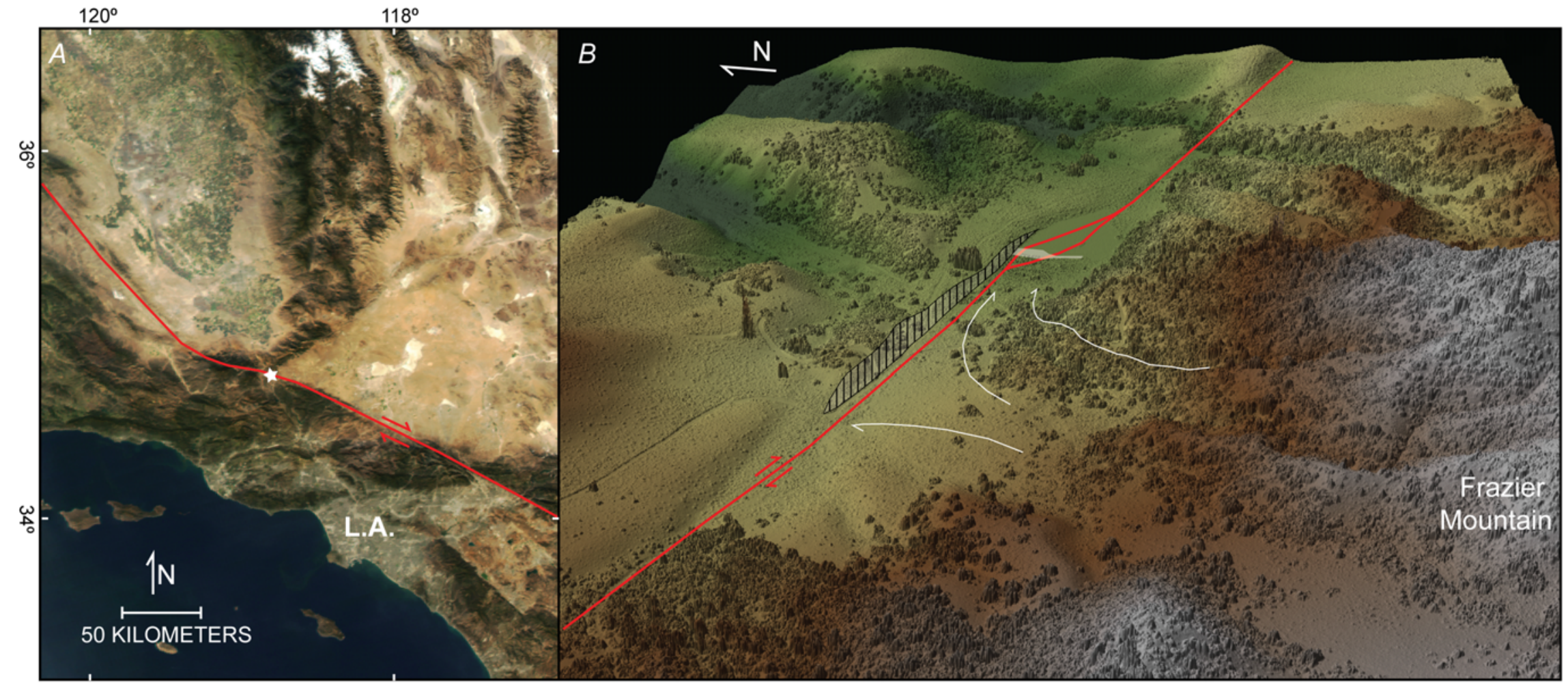

Figure 1. Imagery showing location and tectonic setting of Frazier Mountain paleoseismic site (reproduced from Scharer and others, 2014a). A, Star shows location of site (lat $34.8122^{\circ} \mathrm{N}$., long $118.9034^{\circ} \mathrm{W}$.) along the San Andreas Fault (red line) relative to Los Angeles (L.A.) in southern California. Satellite image from the National Aeronautics and Space Administration accessed through U.S. Department of Agriculture Forest Service Remote Sensing Applications Center. B, Perspective view to the east toward Frazier Mountain paleoseismic site constructed from B4 LiDAR Project dataset (Bevis and others, 2005). Scale is variable, but image shows $\sim 1 \mathrm{~km}$ of the San Andreas Fault (red lines). Elevation ranges from 1,350 to 1,210 m. Drainage northward off Frazier Mountain is currently diverted into the site by a south-facing ridge (striped pattern) that blocks connection to surface channels north of the fault. White arrows show general drainage pattern across fan. White shading shows the location of T1. 


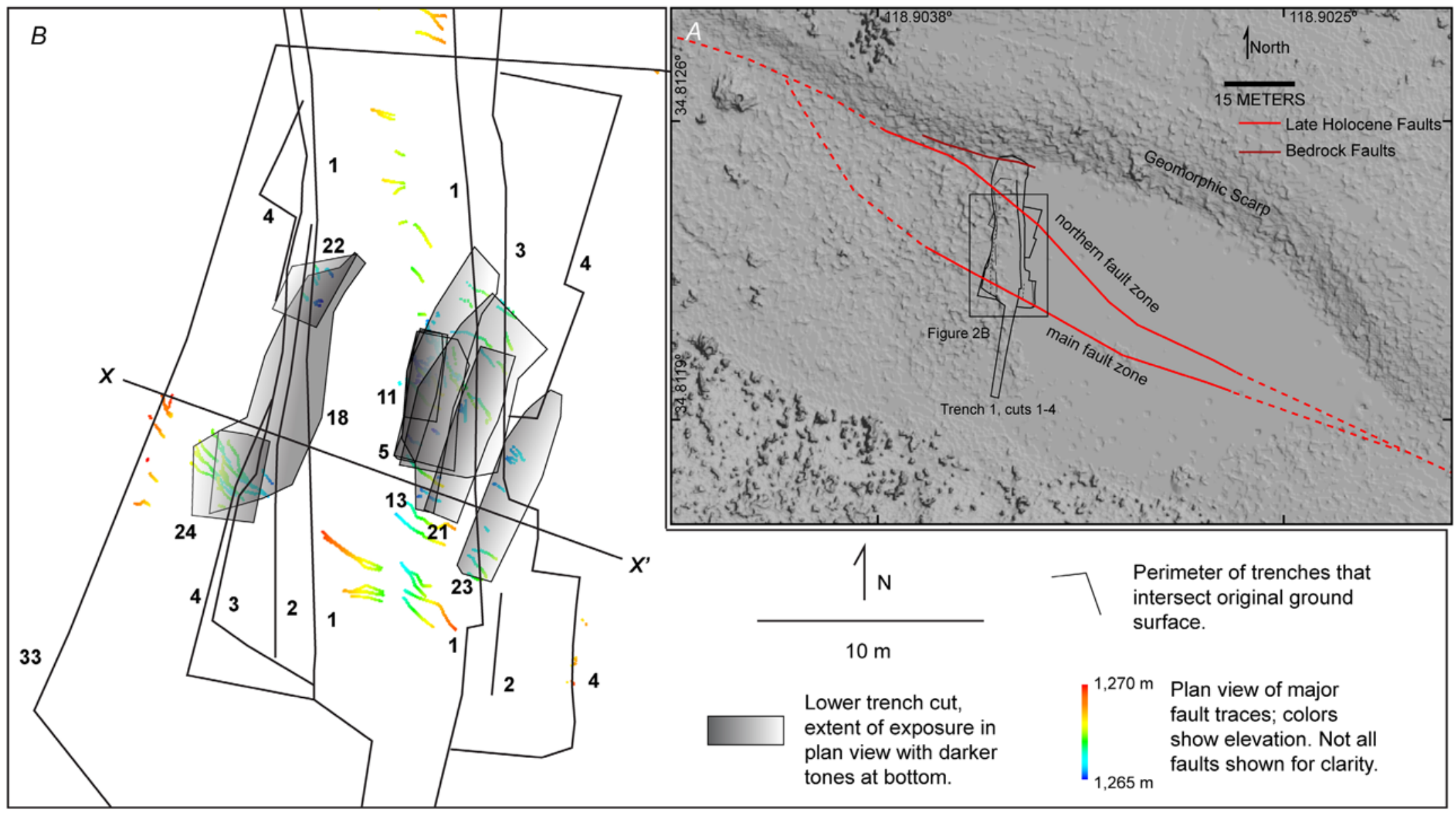

C

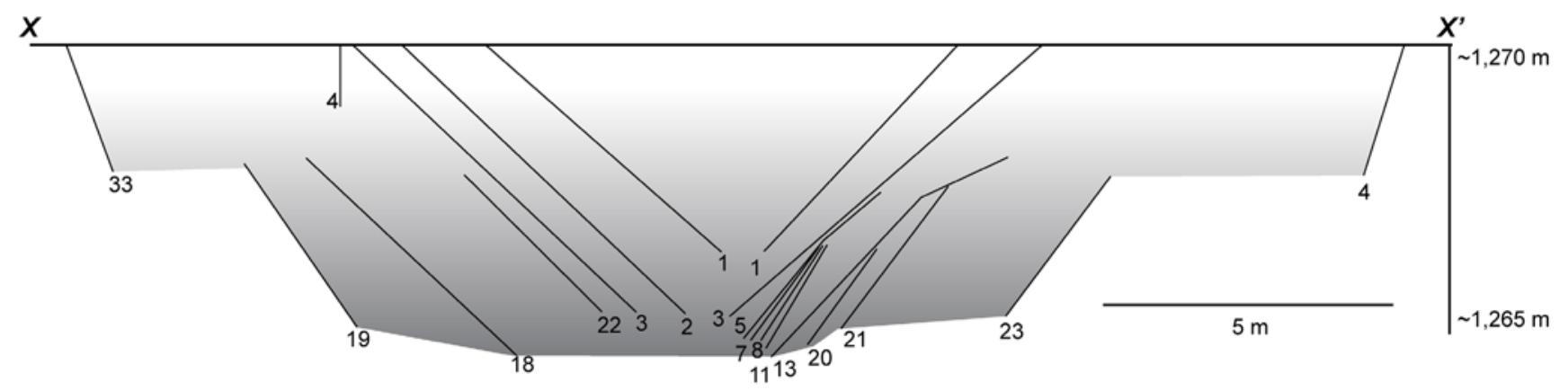


Figure 2. Maps and cross section showing trench 1 (T1) excavations within the geomorphic depression at Frazier Mountain paleoseismic site. $A$, Hillshade basemap from lidar of Frazier Mountain site, showing T1 and the northern and main fault zones. Locations outside T1 are constrained by other trenches not shown here (Scharer and others, 2014b). B, Trench map of T1 excavations, with significant faults (colored lines) projected from sloping trench walls into plan view. The excavations presented in this report are gray, the darkest shade shows the downdip extent of each cut. $C$, Simplified cross-section of T1 excavation showing the nested geometry of the cuts. Note that none of the cuts in this report extend to the ground surface. Some cuts are projected onto line $X-X$ '. 


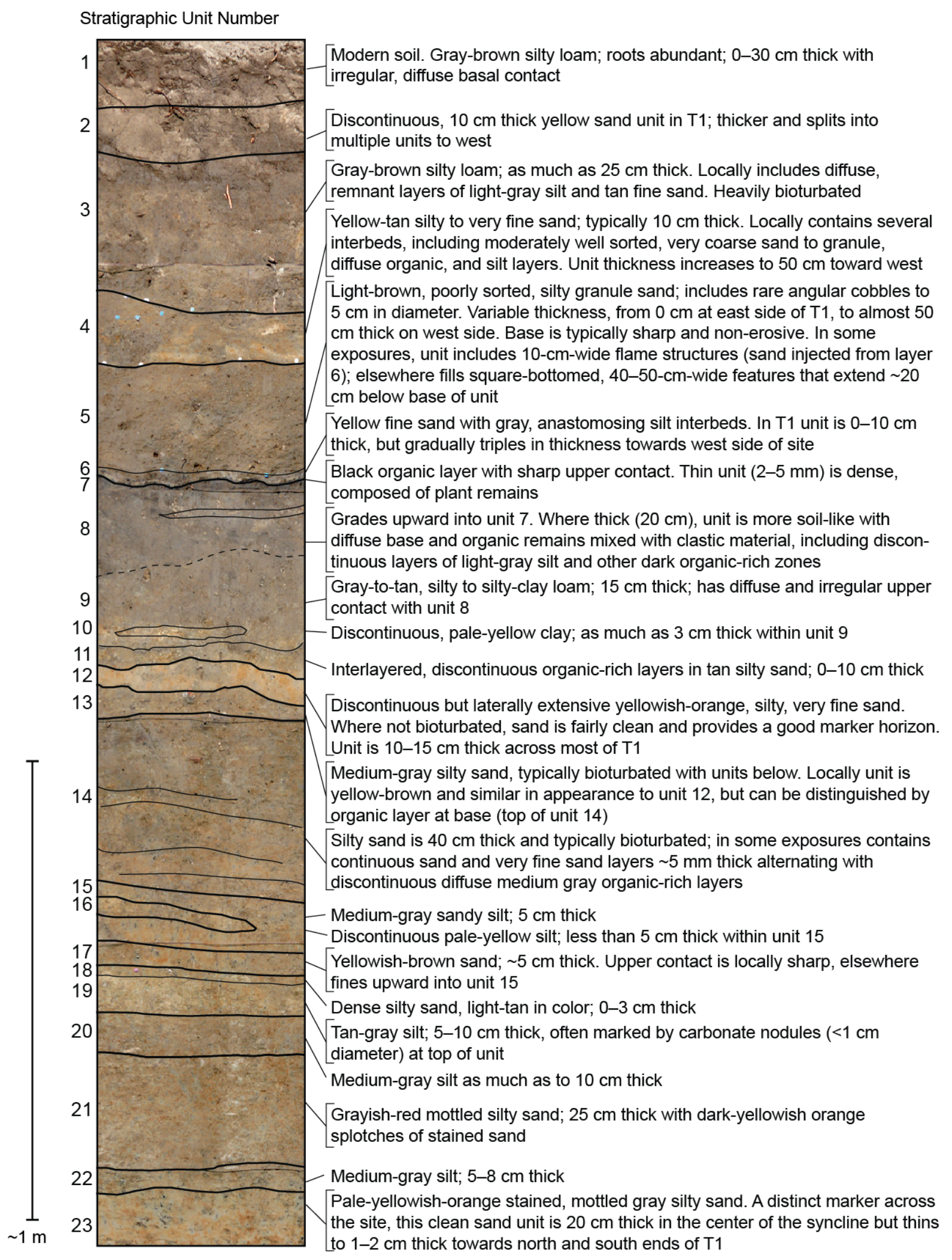

Figure 3. Composite stratigraphic column and unit descriptions of sediments exposed in trench 1 (T1) at Frazier Mountain paleoseismic site. Stratigraphic unit numbers correlate with numbers on trench logs (sheets 1-3). 


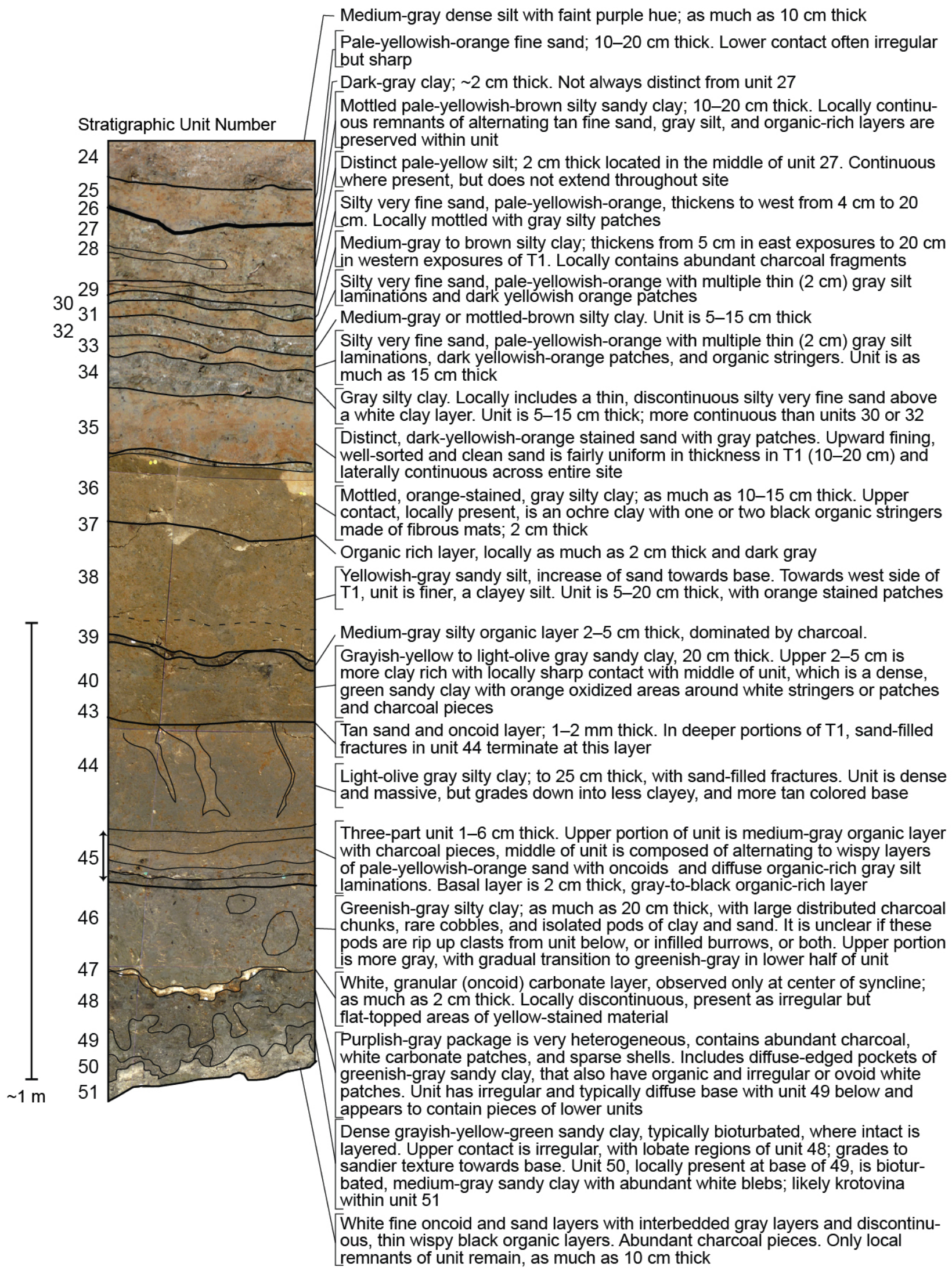

Figure 3-Continued 


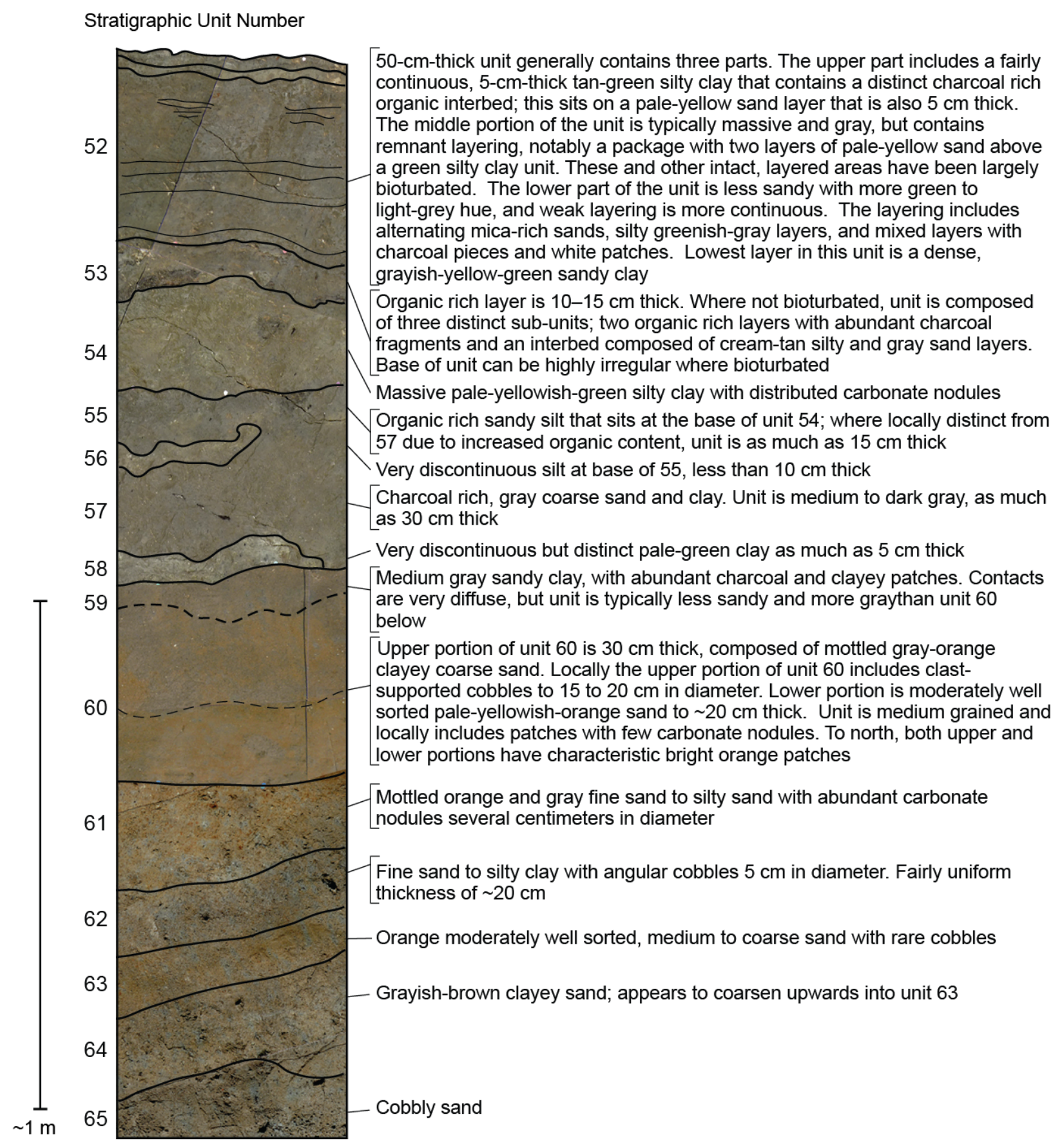

Figure 3-Continued 

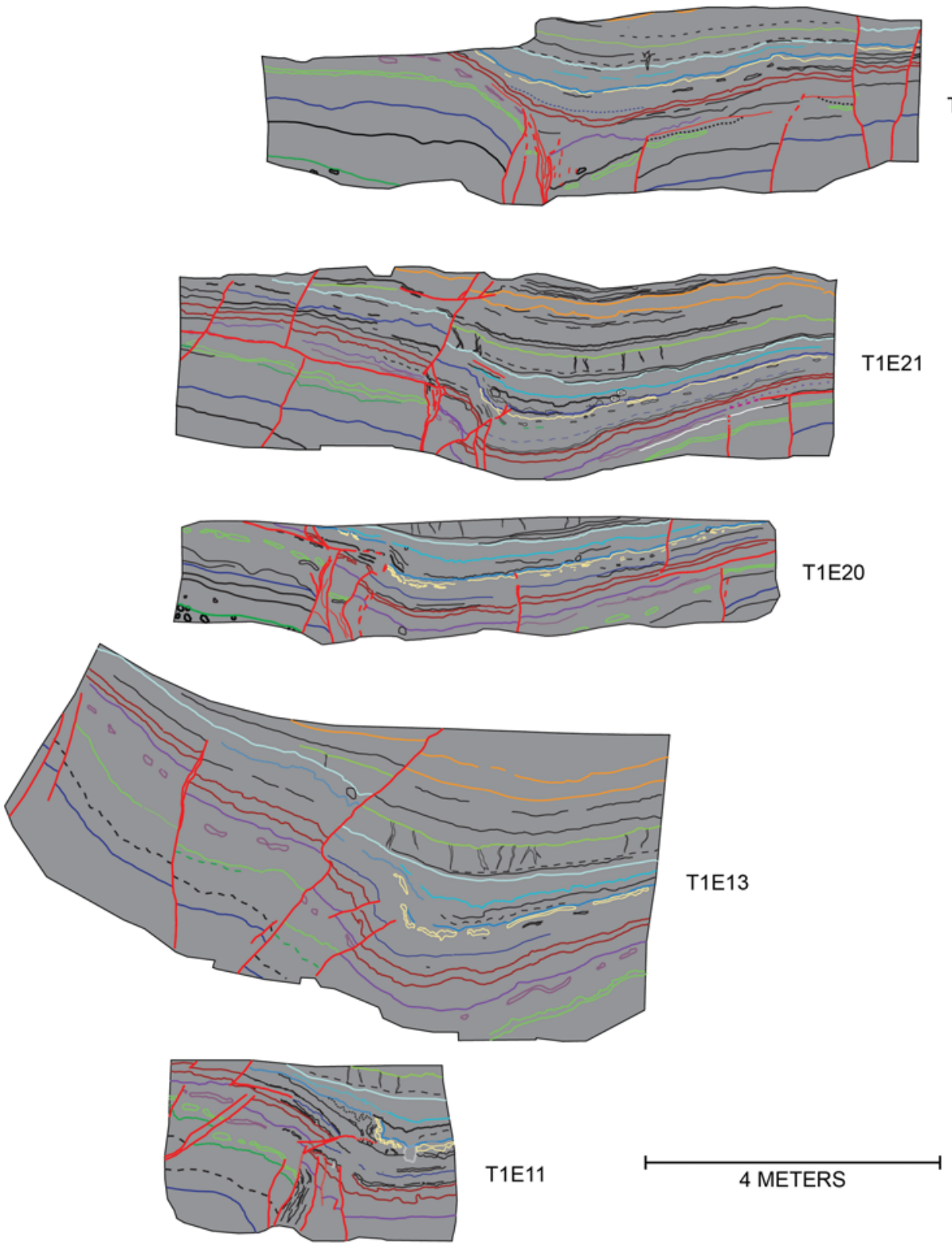

Figure 4. Composite images of simplified trench 1 (T1) logs from deep excavations, derived from sheets 1-3. Logs are arranged by eastern-most to western-most exposure from top to bottom, and aligned perpendicular to the average trend of T1. West wall trenches have been reversed so that north is on the left for all trenches. The top of each trench is not the same elevation for all cuts (fig. 2C). The northern fault zone trends to the northwest, as seen by a gradual northward shift of the fault zone from eastern cuts to western cuts. The main fault zone (fig. 2) was exposed only in T1W18 and T1W24. Logs illustrate how the wavelength of the fold increases from east to west. 


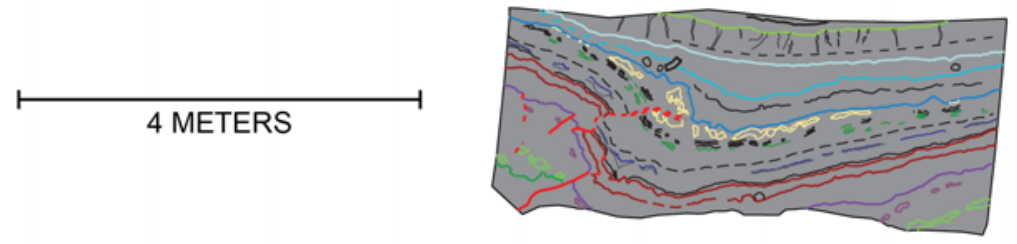

T1E7
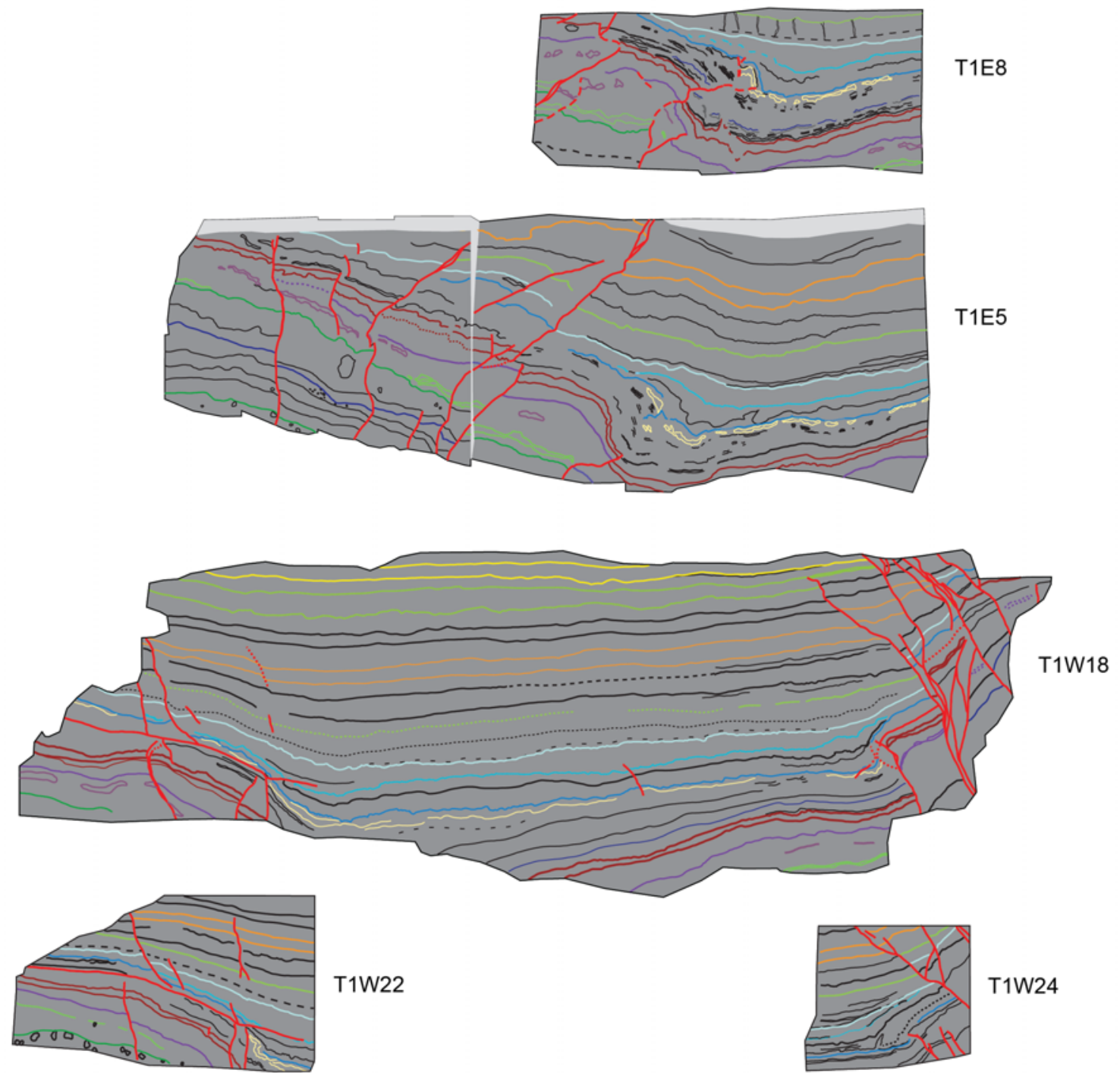

T1W22

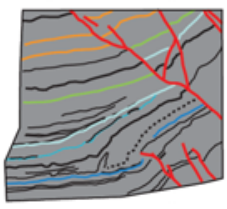

T1W24

Figure 4-Continued 


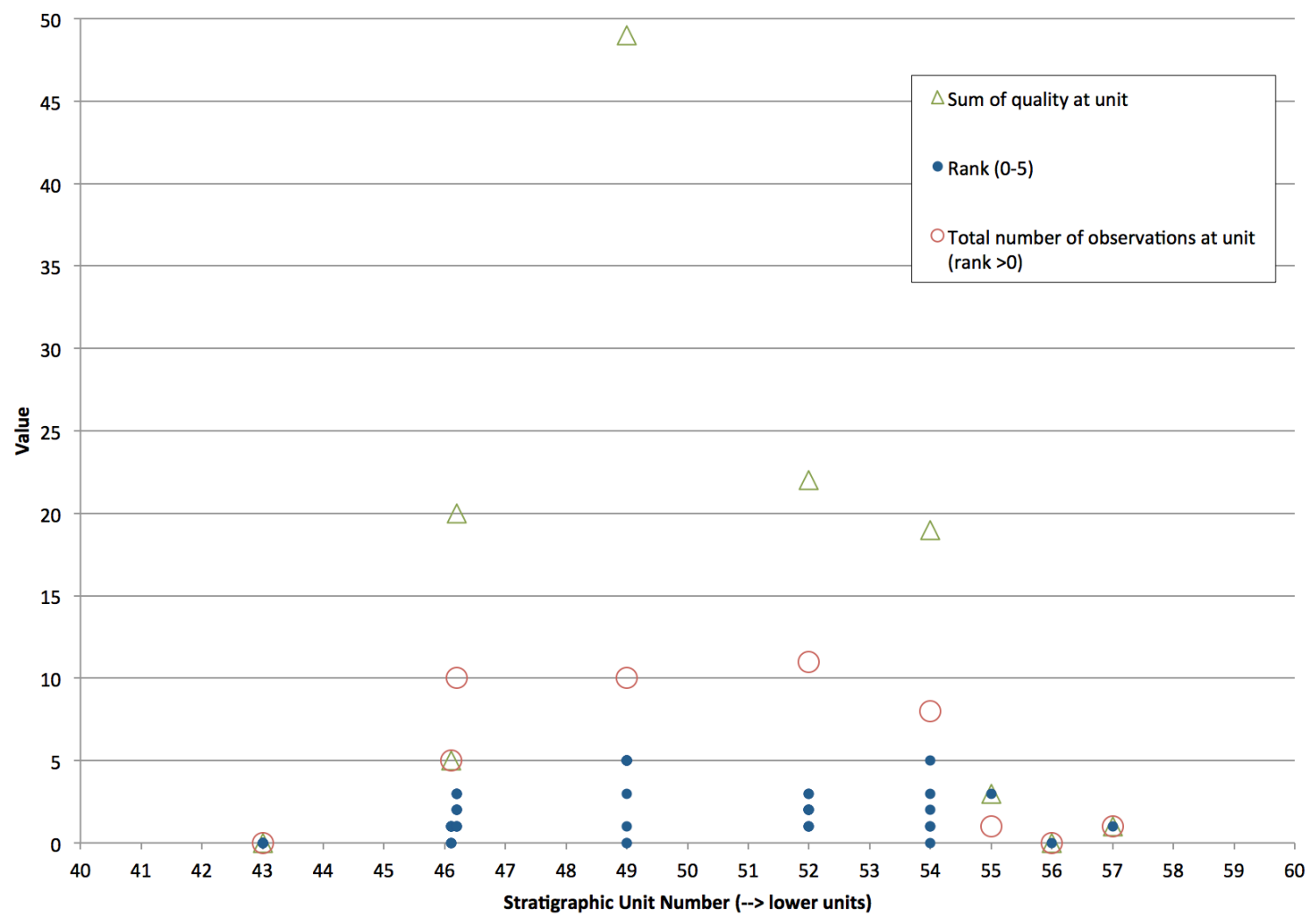

Figure 5. Plot showing event quality for each stratigraphic unit in trench 1 (T1) cuts 5-24. Values are from Appendix and show the range of event quality (0-5), total number of event observations, and the sum of the event quality for each unit. Units 46.1, 46.2, 49, and 54 all have high-quality event indicators ( $\geq 4)$ and the sum of the quality of the event indicators and for these units is high; deformation associated with the other layers is more complex. [It is unclear if the deformation associated with unit 46 represents one or two earthquakes; we have plotted the evidence separately here; combining the evidence (unit 46.1 and unit 46.2) into a single event would produce a sum of quality of 25.] The maximum event quality for unit 52 is only 3 , as deformation at this horizon is poor and complicated by younger faults. The deformation during unit 55 is observed in one location, but is substantial (3). In combination, we consider it very likely that large earthquakes occurred during deposition of units 46,49 , and 54 , likely that a large earthquake occurred during deposition of unit 52 , and probable that a large earthquake occurred during deposition of unit 55. 


\section{Appendix}

Table A1. Location and quality of event evidence from the Frazier Mountain paleoseismic site, trench 1, cuts 5-24, San Andreas Fault, southern California (2010-2012).

[See Event Evidence section and table 1 for discussion of event quality, and figure 5 for a plot of the event quality organized by stratigraphic unit. Abbreviations: fiss, fissure; ft, upward termination of fault tip; fz, fault zone; gs, growth strata; tc, thickness changes; c, cracking; laf, low-angle fault]

\begin{tabular}{|c|c|c|c|c|c|c|c|c|c|}
\hline $\begin{array}{l}\text { Likely unit } \\
\text { of event } \\
\text { horizon }\end{array}$ & $\begin{array}{c}\text { Trench } \\
\text { cut } \\
\text { label }\end{array}$ & $\begin{array}{l}\text { Meter } \\
\text { on } \\
\text { cut }\end{array}$ & $\begin{array}{c}\text { Event } \\
\text { evidence } \\
\text { type }\end{array}$ & $\begin{array}{l}\text { Lowest } \\
\text { affected } \\
\text { unit }\end{array}$ & $\begin{array}{l}\text { Highest } \\
\text { affected } \\
\text { unit }\end{array}$ & $\begin{array}{c}\text { Quality } \\
\text { of event } \\
\text { evidence }\end{array}$ & $\begin{array}{c}\text { No. of } \\
\text { observations }\end{array}$ & $\begin{array}{l}\text { Sum of } \\
\text { quality }\end{array}$ & Description and interpretation of event evidence \\
\hline 24 & T1W18 & 10 & $\mathrm{ft}$ & 25 & 23 & 5 & 1 & 5 & $\begin{array}{l}\text { Strand of main fault zone offsets unit 25, juxtaposing different } \\
\text { thicknesses of unit } 25 \text { on either side of fault, indicative of } \\
\text { large lateral slip. Unit } 24 \text { shows slight thickness changes } \\
\text { across this fault, suggesting the earthquake occurred early in } \\
\text { the deposition of unit } 24\end{array}$ \\
\hline 37 & T1E13 & $2-9$ & fz, tc & 38 & 36 & 1 & 1 & 1 & $\begin{array}{l}\text { Units } 39 \text { through } 36 \text { thicken slightly across this section. No } \\
\text { causal fault evident. However, younger faulting in meter } 5 \\
\text { juxtaposes units on the north that are thinner, which would be } \\
\text { expected along that margin of the basin. This suggests the } \\
\text { thickness changes merely represent slight downhill } \\
\text { thickening characteristic of the deposits in this part of the site }\end{array}$ \\
\hline 43 & T1E7 & $3-5$ & c & 43 & 43 & 0 & 16 & 0 & $\begin{array}{l}\text { Multiple weakly expressed cracks on this surface cut through } \\
\text { unit } 44 \text {. Most are short }(<10 \mathrm{~cm}) \text {, no offset of unit } 43 \text { is } \\
\text { observed across the cracks and most cracks do not cut across } \\
\text { the unit } 44 / 45 \text { contact. None of the cracks are connected to } \\
\text { faults below. Cracks could be the product of desiccation at } \\
\text { the site, or perhaps related to ground shaking at the site } \\
\text { resulting from a nearby earthquake (on or off the San } \\
\text { Andreas Fault) }\end{array}$ \\
\hline 43 & T1E8 & $3-5$ & c & 43 & 43 & 0 & 10 & 0 & See above \\
\hline 43 & T1E11 & $3-5$ & $\mathrm{c}$ & 43 & 43 & 0 & 5 & 0 & See above \\
\hline 43 & T1E13 & $3-5$ & c & 43 & 43 & 0 & 10 & 0 & See above \\
\hline 43 & T1E20 & $3-5$ & c & 43 & 43 & 0 & 9 & 0 & See above \\
\hline 43 & T1E21 & $3-5$ & C & 43 & 43 & 0 & 7 & 0 & See above \\
\hline 43 & T1E23 & $3-5$ & C & 43 & 43 & 0 & 2 & 0 & See above \\
\hline
\end{tabular}




\begin{tabular}{|c|c|c|c|c|c|c|c|c|}
\hline $\begin{array}{l}\text { Likely unit } \\
\text { of event } \\
\text { horizon }\end{array}$ & $\begin{array}{c}\text { Trench } \\
\text { cut } \\
\text { label }\end{array}$ & $\begin{array}{l}\text { Meter } \\
\text { on } \\
\text { cut }\end{array}$ & $\begin{array}{c}\text { Event } \\
\text { evidence } \\
\text { type }\end{array}$ & $\begin{array}{c}\text { Lowest } \\
\text { affected } \\
\text { unit }\end{array}$ & $\begin{array}{c}\text { Highest } \\
\text { affected } \\
\text { unit }\end{array}$ & $\begin{array}{c}\text { Quality } \\
\text { of event } \\
\text { evidence }\end{array}$ & $\begin{array}{c}\text { No. of } \\
\text { observations }\end{array}$ & $\begin{array}{l}\text { Sum of } \\
\text { quality }\end{array}$ \\
\hline 46.1 & T1W18 & $2-12$ & tc & 46 & 39 & 1 & 1 & 1 \\
\hline
\end{tabular}
of fold, with strongest thinning on south side where the package decreases in thickness by about half. Overall, the pattern matches thickness changes of older layers. Because no fault cuts unit 46 , we cannot identify a causal fault. If these thickness changes are indicative of an earthquake, it was characterized by soft-sediment deformation at the ground surface when unit 46 was the ground surface. The faults that cut through to unit 49 may have been re-activated if this is the case. Alternatively, the thickness changes may be attributable to continued filling of a depression formed from an earlier earthquake, or simply reflect the depositional gradient of the basin. Given these uncertainties, this indicator quality is ranked low

46

T1E7 1-5 tc

46
46.1
$\mathrm{T} 1 \mathrm{E} 7$

1

tc

(c)

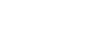

44

1

There is a $5^{\circ}$ difference between the apparent dip of units 45 and 47 , and units 45 through 44 decrease in thickness by half where unit 46 pinches out. No fault cuts through unit 46 . This pattern could be the product of continued filling from previous earthquakes(s) rather than a separate folding event

Units 44 and 45 double in thickness across this 2-m span, although the change in angle between the base of units 45 and 47 is minor. The basal layers of unit 45 either buttress or thin across this limb. This thickness change (at northern margin of fold) is also seen in T1W18, T1E5, and T1E21. This pattern could be the product of continued filling from previous earthquakes rather than a separate folding event

Unit 45 gradually thins by 50 percent across exposure; interlayered subunits of unit 45 pinch out against the northern fold limb. Exposure did not continue high enough to see expression of unit 43 contact, but given proximal exposures at the site, this is considered very weak evidence for an earthquake during deposition of unit 46

This exposure does not show thickness changes of units 45 and 44 as a set; the basal part (unit 45), comprising alternating sand and mud, thins against the fold limb and the upper part (unit 44) actually thickens up the northern fold limb. This depositional pattern could reflect less bioturbation and better preservation in the deeper part of a fold that was produced earlier; essentially showing that the sag was filled by unit 44 


\begin{tabular}{|c|c|c|c|c|c|c|c|c|c|}
\hline $\begin{array}{l}\text { Likely unit } \\
\text { of event } \\
\text { horizon }\end{array}$ & $\begin{array}{c}\text { Trench } \\
\text { cut } \\
\text { label }\end{array}$ & $\begin{array}{l}\text { Meter } \\
\text { on } \\
\text { cut }\end{array}$ & $\begin{array}{c}\text { Event } \\
\text { evidence } \\
\text { type }\end{array}$ & $\begin{array}{l}\text { Lowest } \\
\text { affected } \\
\text { unit }\end{array}$ & $\begin{array}{c}\text { Highest } \\
\text { affected } \\
\text { unit }\end{array}$ & $\begin{array}{l}\text { Quality } \\
\text { of event } \\
\text { evidence }\end{array}$ & $\begin{array}{c}\text { No. of } \\
\text { observations }\end{array}$ & $\begin{array}{l}\text { Sum of } \\
\text { quality }\end{array}$ & Description and interpretation of event evidence \\
\hline 46.1 & T1E5 & $3-9$ & tc & 46 & 43 & 0 & 1 & 0 & $\begin{array}{l}\text { In this longer exposure, the most significant thickness changes } \\
\text { of unit } 45 \text { and } 44 \text { are the product of younger faulting that } \\
\text { offsets these units in meters } 4-5 \text { and juxtapose thinner parts } \\
\text { from the north. This suggests that the thickness changes are } \\
\text { largely a product of uphill thinning, rather than filling of a } \\
\text { earthquake-generated depression. Almost no thickness } \\
\text { changes are expressed in the center of the fold, leading to a } \\
\text { rank of } 0\end{array}$ \\
\hline 46.1 & T1E8 & $3-5$ & tc & 46 & 43 & 0 & 1 & 0 & Similar to 46.1 for T1E7 \\
\hline 46.1 & T1W22 & $2-4$ & tc & 46 & 43 & 0 & 1 & 0 & $\begin{array}{l}\text { Thickness changes are small (<20 percent) in units } 45 \text { and } 44 \text {, } \\
\text { mostly due to gradual change in unit } 45 \text { thickness and } \\
\text { younger faulting juxtaposing different thicknesses. Compared } \\
\text { to other exposures, the change in thickness is less, suggesting } \\
\text { these thickness changes are the product of downhill } \\
\text { thickening, natural variation, or perhaps continued filling } \\
\text { from an earlier event. The deformation and the exact horizon } \\
\text { are difficult to discern, so the quality is ranked as zero }\end{array}$ \\
\hline $46.1 / .2$ & T1E21 & $1-9$ & tc & 46 & 43 & 0 & 1 & 0 & $\begin{array}{l}\text { In center of the fold, thickness changes of units } 46-44 \text { are } \\
\text { minor ( } \sim 20 \text { percent). The contact between units } 48 \text { and } 49 \text { is } \\
\text { obscure in this most distal exposure, making the timing of } \\
\text { any folding and subsequent filling difficult to discern. There } \\
\text { is a bedding parallel fault at meter } 4 \text { that postdates any } \\
\text { deformation during deposition of unit } 46\end{array}$ \\
\hline 46.2 & T1W24 & $0-2$ & tc & 47 & 45 & 3 & 1 & 3 & $\begin{array}{l}\text { Unit } 46 \text { decreases in thickness by } ~ 30 \text { percent, pinching out } \\
\text { completely across the southern fold limb. In this exposure, } \\
\text { unit } 46 \text { contains blocks of older units, including speckled unit } \\
48 \text { and green clay fragments from unit } 49 \text {. This is the only } \\
\text { exposure where underlying unit } 48 \text { is uniform in thickness, } \\
\text { providing better differentiation between an older event (at } \\
\text { unit } 49 \text { ) and additional folding of unit } 47 \text { or the early stages } \\
\text { of unit } 46 \text {. No faulting is directly associated with the } \\
\text { thickness changes in unit } 46 \text {, although it could be the product } \\
\text { of a fold scarp manifest above the faulting in meter } 1\end{array}$ \\
\hline 46.2 & T1E11 & $2-4$ & tc & 47 & 45 & 3 & 1 & 3 & $\begin{array}{l}\text { Unit } 46 \text { triples in thickness over this short span. Unit } 48 \text { has } \\
\text { relatively uniform thickness in the syncline in meter } 3 \text {, } \\
\text { providing better confidence that the ground had filled after an } \\
\text { event at unit } 49 \text {, but its lower contact is not clear across the } \\
\text { northern fold limb }\end{array}$ \\
\hline
\end{tabular}




\begin{tabular}{|c|c|c|c|c|c|c|c|c|c|}
\hline $\begin{array}{c}\text { Likely unit } \\
\text { of event } \\
\text { horizon }\end{array}$ & $\begin{array}{c}\text { Trench } \\
\text { cut } \\
\text { label }\end{array}$ & $\begin{array}{l}\text { Meter } \\
\text { on } \\
\text { cut }\end{array}$ & $\begin{array}{l}\text { Event } \\
\text { evidence } \\
\text { type }\end{array}$ & $\begin{array}{l}\text { Lowest } \\
\text { affected } \\
\text { unit }\end{array}$ & $\begin{array}{l}\text { Highest } \\
\text { affected } \\
\text { unit }\end{array}$ & $\begin{array}{c}\text { Quality } \\
\text { of event } \\
\text { evidence }\end{array}$ & $\begin{array}{c}\text { No. of } \\
\text { observations }\end{array}$ & $\begin{array}{l}\text { Sum of } \\
\text { quality }\end{array}$ & Description and interpretation of event evidence \\
\hline
\end{tabular}

thirds of the fold (its lower contact merges with units 49-51

on the northern fold limb). Above the syncline formed by unit 48, unit 46 triples in thickness between meters 1 and 4 . Unit 46 also contains blocks and fragments of unit 48, suggesting that an event disrupted the ground surface after unit 48 was deposited, during the deposition of unit 46

46

Unit 46 thickens in this 3-m section, merging with unit 48 on uplifted northern limb of fold. The angular difference between units 47 and 45 is large $\left(\sim 20^{\circ}\right)$. Cobbles in unit 46 in this exposure suggest that unit 46 accumulated fairly rapidly (in other words, in flow substantial enough to transport 10cm-diameter cobbles). Unit 48 pinches out across the fold limb at this location (either eroded off the top of a fold scarp or thinner due to preexisting fold), making the interpretation of this deformation less clear than in T1W24

2 Unit 46 almost doubles in thickness over this 2-m section, then maintains same thickness for several meters to south. No causal fault is evident, although the thickness changes could be the product of soft-sediment deformation above fault in meter 2, as suggested by fanning dips across this feature. Quality is lowered as there is only a few degree difference between the apparent dip of the unit 47 and unit 45 contacts Thickness of unit 46 more than doubles in the center of the fold. Unit 47 remains intact over the limb and is folded and then thickened. Fragments of unit 48 in unit 46 suggest the ground was deformed after deposition of unit 48 . No fault can be specifically attributed to this deformation, rather, it would be the product of soft-sediment deformation or a fold scarp developed above one of the faults that terminate at a lower layer

$\begin{array}{llllllll}46.2 & \text { T1W22 } & 2-4 & \text { tc } & 47 & 46 & 2 & 1\end{array}$

$2 \quad$ Unit 46 thins across the northern fold limb reducing in thickness by about 30 percent. A minor fault terminates at the base of unit 46 in meter 2, although it has such small offset that its upward termination is not clear. This deformation could be the product of an earthquake during the deposition of unit 46, or reflect continued filling of an earthquake at unit 49 


\begin{tabular}{|c|c|c|c|c|c|c|c|c|c|}
\hline $\begin{array}{l}\text { Likely unit } \\
\text { of event } \\
\text { horizon }\end{array}$ & $\begin{array}{l}\text { Trench } \\
\text { cut } \\
\text { label }\end{array}$ & $\begin{array}{l}\text { Meter } \\
\text { on } \\
\text { cut }\end{array}$ & $\begin{array}{l}\text { Event } \\
\text { evidence } \\
\text { type }\end{array}$ & $\begin{array}{l}\text { Lowest } \\
\text { affected } \\
\text { unit }\end{array}$ & $\begin{array}{l}\text { Highest } \\
\text { affected } \\
\text { unit }\end{array}$ & $\begin{array}{l}\text { Quality } \\
\text { of event } \\
\text { evidence }\end{array}$ & $\begin{array}{c}\text { No. of } \\
\text { observations }\end{array}$ & $\begin{array}{l}\text { Sum of } \\
\text { quality }\end{array}$ & Description and interpretation of event evidence \\
\hline 46.2 & T1E5 & $6-9$ & tc & 47 & 45 & 1 & 1 & 1 & $\begin{array}{l}\text { Unit } 46 \text { almost doubles in thickness across a 2-meter section. } \\
\text { Here unit } 46 \text { is a gray-green clay that does not have blocks } \\
\text { from other layers, yet unit } 48 \text { pinches out against the northern } \\
\text { fold limb. No fault cuts to the base of } 46 \text {. This pattern could } \\
\text { be produced by continued onlapping sediment across a fold } \\
\text { scarp produced during deposition of unit } 49 \text {; however, we can } \\
\text { not discount the possibility that separate, distributed } \\
\text { deformation and folding occurred during deposition of unit } \\
46\end{array}$ \\
\hline 46.2 & T1W18 & $2-12$ & tc & 47 & 45 & 1 & 1 & 1 & $\begin{array}{l}\text { Unit } 46 \text { thickens above the syncline, but the apparent dip of } \\
\text { units } 45 \text { and } 47 \text { over the primary fold hinges (meters } 3 \text { and } \\
\text { 11) differ by only a few degrees. For this reason, and in the } \\
\text { absence of a causal fault, it is possible that the thickness } \\
\text { changes reflect continued filling from a previous earthquake }\end{array}$ \\
\hline 46.2 & T1W18 & $7-8$ & $\mathrm{ft}$ & 47 & 45 & 1 & 1 & 1 & $\begin{array}{l}\text { Minor fault with displacement decreasing upward, terminates in } \\
\text { the base of unit } 46 \text {. Mechanically, this could be a brittle } \\
\text { accommodation of folding seen elsewhere in unit } 48 \text { (layers } \\
\text { are locally horizontal). The fault does not continue downward } \\
\text { into underlying units, suggesting it could be part of a } \\
\text { stepping, en echelon fault or ductile deformation of lower } \\
\text { units }\end{array}$ \\
\hline 49 & T1W24 & $0-2$ & tc & 51 & 47 & 5 & 1 & 5 & $\begin{array}{l}\text { Faulting continues up through unit } 50 \text {, terminating in a } \\
\text { thickened and deformed unit } 49 \text {. Here unit } 48 \text { has a fairly } \\
\text { uniform thickness, and restoring upper layers to horizontal } \\
\text { would rotate the causal fault to a } \sim 60^{\circ} \text { dip to the south, with } \\
\text { sublayers of unit } 50 \text { draping over this fault tip, suggestive of a } \\
\text { fold scarp produced when unit } 49 \text { was at the ground surface }\end{array}$ \\
\hline 49 & T1E11 & $3-4$ & gs & 51 & 47 & 5 & 1 & 5 & $\begin{array}{l}\text { Low-angle fault offsets units through the top part of unit } 52 \text {. } \\
\text { Units } 51 \text { through } 49 \text { are strongly folded and truncated by the } \\
\text { base of unit } 48 \text {. Unit } 48 \text { has fairly uniform thickness across } \\
\text { this section, suggesting that it was a soil that mantled the } \\
\text { earthquake surface }\end{array}$ \\
\hline 49 & T1E13 & $5-8$ & gs & 51 & 47 & 5 & 1 & 5 & $\begin{array}{l}\text { Faulting continues through the middle of unit 52, distributed } \\
\text { deformation affects unit } 51 \text {. Deformation appears to be } \\
\text { product of soft-sediment folding of unit } 49 \text {, followed by soil } \\
\text { formation represented by unit } 48\end{array}$ \\
\hline
\end{tabular}




\begin{tabular}{|c|c|c|c|c|c|c|c|c|c|}
\hline $\begin{array}{l}\text { Likely unit } \\
\text { of event } \\
\text { horizon }\end{array}$ & $\begin{array}{l}\text { Trench } \\
\text { cut } \\
\text { label }\end{array}$ & $\begin{array}{l}\text { Meter } \\
\text { on } \\
\text { cut }\end{array}$ & $\begin{array}{l}\text { Event } \\
\text { evidence } \\
\text { type }\end{array}$ & $\begin{array}{l}\text { Lowest } \\
\text { affected } \\
\text { unit }\end{array}$ & $\begin{array}{l}\text { Highest } \\
\text { affected } \\
\text { unit }\end{array}$ & $\begin{array}{l}\text { Quality } \\
\text { of event } \\
\text { evidence }\end{array}$ & $\begin{array}{c}\text { No. of } \\
\text { observations }\end{array}$ & $\begin{array}{l}\text { Sum of } \\
\text { quality }\end{array}$ & Description and interpretation of event evidence \\
\hline 49 & T1E20 & $2-7$ & gs & 51 & 47 & 5 & 1 & 5 & $\begin{array}{l}\text { Above the faults ending in meter } 2 \text {, there is a } 20^{\circ} \text { difference in } \\
\text { the apparent dip of units } 51 \text { and } 47 \text {. Units } 51 \text { through } 49 \text { are } \\
\text { folded and truncated by the base of unit } 48 \text {, which thickens } \\
\text { across the northern fold limb into the synclinal axis. The } \\
\text { pattern suggests that an earthquake occurred during the later } \\
\text { stages of the deposition of unit } 49\end{array}$ \\
\hline 49 & T1E21 & $4-9$ & gs & 51 & 47 & 5 & 1 & 5 & $\begin{array}{l}\text { Fault offsets unit } 51 \text { and deposition of unit } 49 \text { occurred only } \\
\text { within the syncline; unit } 48 \text { appears to cap that deformation, } \\
\text { although the basal contact is obscure in this exposure }\end{array}$ \\
\hline 49 & T1E5 & $5-9$ & gs, ft & 49 & 47 & 5 & 1 & 5 & $\begin{array}{l}\text { A fault with apparent dip of } \sim 25^{\circ} \text { cuts through units } 53 \text { and } \\
\text { older, terminating as distributed deformation in units } 53 \\
\text { through } 51 \text {. Unit } 48 \text { contains blocks of unit } 49 \text { and older, but } \\
\text { is also organic rich, and thickens across the fold of unit } 51 \text {. } \\
\text { We interpret that units } 51-49 \text { are mixed in the soil horizon of } \\
\text { unit } 48 \text {. Note that removing the post unit } 45 \text { folding (about } \\
15^{\circ} \text { ) would restore the fault to an apparent dip greater than } \\
50^{\circ}\end{array}$ \\
\hline 49 & T1E7 & $1-5$ & gs, ft & 49 & 47 & 5 & 1 & 5 & $\begin{array}{l}\text { Unit } 49 \text { is strongly folded by a low-angle fault, and has a sub } \\
\text { vertical limb in meter } 1 \text {. Unit } 48 \text { is observed on the down- } \\
\text { thrown side, and is composed of an organic-rich mud with } \\
\text { small fragments of unit } 49 \text {. We interpret an earthquake } \\
\text { occurred close to the top of the accumulation of unit } 49 \text { and } \\
\text { that unit } 48 \text { represents the reworking of unit } 49 \text { off the } \\
\text { uplifted northern side of the fault }\end{array}$ \\
\hline 49 & T1E8 & $2-5$ & gs & 49 & 48 & 5 & 1 & 5 & $\begin{array}{l}\text { Unit } 49 \text { is folded and buckled by low-angle fault; faulting is } \\
\text { discrete in the lower half of unit 52, above this distributed } \\
\text { shearing buckles the upper half of unit } 52 \text {. This produces a } \\
\text { subvertical fold limb in unit } 49 \text {. Here unit } 49 \text { continues } \\
\text { farther up on the fold limb than in other exposures, as if it } \\
\text { mantled the surface prior to being folded. }\end{array}$ \\
\hline 49 & T1W18 & $2-12$ & gs & 49 & 47 & 5 & 1 & 5 & $\begin{array}{l}\text { Faults in meter } 11 \text { continue up through unit } 49 \text {, cause } \\
\text { juxtaposition of different unit thicknesses on either side of the } \\
\text { fault. Unit } 49 \text { and } 48 \text { thin across the fold limb, and unit } 48 \\
\text { contains fragments of units } 51-49 \text {. Overall, units } 48 \text { and } 49 \\
\text { increase in thickness by four times in the center of the fold. } \\
\text { Based on the faulting and character of unit } 48 \text {, we interpret } \\
\text { that this event occurred when unit } 49 \text { was at the ground } \\
\text { surface }\end{array}$ \\
\hline
\end{tabular}




\begin{tabular}{|c|c|c|c|c|c|c|c|c|c|}
\hline $\begin{array}{c}\text { Likely unit } \\
\text { of event } \\
\text { horizon }\end{array}$ & $\begin{array}{c}\text { Trench } \\
\text { cut } \\
\text { label }\end{array}$ & $\begin{array}{l}\text { Meter } \\
\text { on } \\
\text { cut }\end{array}$ & $\begin{array}{c}\text { Event } \\
\text { evidence } \\
\text { type }\end{array}$ & $\begin{array}{l}\text { Lowest } \\
\text { affected } \\
\text { unit }\end{array}$ & $\begin{array}{c}\text { Highest } \\
\text { affected } \\
\text { unit }\end{array}$ & $\begin{array}{c}\text { Quality } \\
\text { of event } \\
\text { evidence }\end{array}$ & $\begin{array}{c}\text { No. of } \\
\text { observations }\end{array}$ & $\begin{array}{l}\text { Sum of } \\
\text { quality }\end{array}$ & Description and interpretation of event evidence \\
\hline
\end{tabular}

49

T1W22

51

47

1

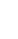

49

T1W18 2-5 gs

52

47

1

49

T1E13 2

$\mathrm{ft}$

52

45

0

1

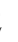

T1E13 4-5 ft

52

47

0

2

49 tc
$53 \quad 51$
3

Units 51 and older are strongly deformed by a steeply dipping
fault in meter 3. Unit 49 pinches out across this deformation, suggesting it was deposited into relief generated by an event.

The overlying unit (48) has fairly constant thickness,

supporting an event during deposition of unit 49

1 Faulting in meter 3 is complicated by a younger low-angle

fault, but continues to near the top of unit 52. Units 48-51 are thin on the uplifted (north) side of the fault zone, such that it is not clear where the fault terminates in this section. We assign the faulting to an event during deposition of unit 49, but the faulting is also compatible with an earthquake during deposition of unit 52

Subvertical fault produces $50 \mathrm{~cm}$ of vertical separation of units 53 and older and likely also offsets the basal part of unit 52. The fault terminates in a soil that is the attenuated equivalent of units 51 through 45, so assignment of the upper termination is not possible

Two faults offset the basal silt in unit 52, but the termination of faults within this unit is less clear. A discontinuous sand layer at the top of unit 52 may be displaced (with the same slip direction as the older units), but a discrete fault through the upper part of unit 52 was not observed. This deformation could be the product of two events, the first occurring during the deposition of unit 52 and a second that reactivated the faults and folded unit 50. However, the older of these events is not required to create the geometry evident in this exposure, and other exposures more clearly indicate that these faults were active in an event at unit 49

Unit 52 is almost three times thicker in center of fold, whereas underlying unit 53 has constant thickness. Causal fault is not evident, but could be product of folding during activity on fault zone in meter 3. Basal sand unit appears to pinch out on northern limb, suggesting that the event occurred when unit 53 was the ground surface or early in the accumulation of unit 52 


\begin{tabular}{|c|c|c|c|c|c|c|c|c|c|}
\hline $\begin{array}{c}\text { Likely unit } \\
\text { of event } \\
\text { horizon }\end{array}$ & $\begin{array}{c}\text { Trench } \\
\text { cut } \\
\text { label }\end{array}$ & $\begin{array}{l}\text { Meter } \\
\text { on } \\
\text { cut }\end{array}$ & $\begin{array}{c}\text { Event } \\
\text { evidence } \\
\text { type }\end{array}$ & $\begin{array}{c}\text { Lowest } \\
\text { affected } \\
\text { unit }\end{array}$ & $\begin{array}{c}\text { Highest } \\
\text { affected } \\
\text { unit }\end{array}$ & $\begin{array}{c}\text { Quality } \\
\text { of event } \\
\text { evidence }\end{array}$ & $\begin{array}{c}\text { No. of } \\
\text { observations }\end{array}$ & $\begin{array}{l}\text { Sum of } \\
\text { quality }\end{array}$ & Description and interpretation of event evidence \\
\hline 52 & T1E21 & $3-9$ & gs, ft & 53 & 51 & 2 & 1 & 2 & more than doubles in thickness across a series of \\
\hline
\end{tabular}
crosscutting faults in meter 4. Faulting here is complex; one fault that terminates in unit 50 appears to cut lower faults that only show offset through unit 52. Rotating the top of unit 53 to horizontal orients the southern fault traces in meter 4 to a $\sim 60^{\circ}$ southward dip. Preservation of the upper sandy part of unit 52 north of the fault suggests a preexisting fold scarp north of the faulting during deposition of unit 49. It is not clear from this exposure if the variation in thickness in unit 52 is solely attributable to an event at the top of unit 53/base of unit 52, so the evidence is equivocal As a whole, unit 52 shows slight (20 percent) thickening in the center of the fold. Upper sandy layers in unit 52 do not continue across the uplifted (north) side, suggesting they filled a broad syncline that had a fold limb north of the event that occurred during deposition of unit 49

Unit 52 almost doubles in thickness across this span. Much of this is reflected in the preservation of the upper part of unit 52 , especially in the southern-thickening wedge of sand on the uplifted side of the fault. The location of the thickening of the upper unit suggests a preexisting fold scarp that was located north of the faulting produced during deposition of unit 49

Two faults cut though unit 53 and the basal sand of unit 52 . Contacts above this are less clear, but the faulting does not appear to continue above the middle of unit 52. This exposure appears to show the best evidence for two separate deformation events (the first faulted the base of unit 52 and a younger event produced a fold scarp at the tip of fault that cuts through unit 52 and deforms unit 49)

The upper part of unit 52 increases in thickness on the hanging wall of the low-angle fault. This thickness change may be the product of a growth strata package that would have accumulated during the deposition of unit 52. Because unit 48 does not appear to contain the sand layers of unit 52 and has a fairly uniform thickness, we do not interpret that the thinning of the upper sand layers in unit 52 is a product of scarp degradation downward into that unit. Low event quality due to uncertainty about this interpretation 


\begin{tabular}{|c|c|c|c|c|c|c|c|c|c|}
\hline $\begin{array}{c}\text { Likely unit } \\
\text { of event } \\
\text { horizon }\end{array}$ & $\begin{array}{c}\text { Trench } \\
\text { cut } \\
\text { label }\end{array}$ & $\begin{array}{l}\text { Meter } \\
\text { on } \\
\text { cut }\end{array}$ & $\begin{array}{c}\text { Event } \\
\text { evidence } \\
\text { type }\end{array}$ & $\begin{array}{c}\text { Lowest } \\
\text { affected } \\
\text { unit }\end{array}$ & $\begin{array}{c}\text { Highest } \\
\text { affected } \\
\text { unit }\end{array}$ & $\begin{array}{c}\text { Quality } \\
\text { of event } \\
\text { evidence }\end{array}$ & $\begin{array}{c}\text { No. of } \\
\text { observations }\end{array}$ & $\begin{array}{l}\text { Sum of } \\
\text { quality }\end{array}$ & Description and interpretation of event evidence \\
\hline
\end{tabular}

meter 2 and meter 3 than on the northern limb. Most of this

thickness change occurs across younger faults that likely

continue up to unit 49. However, the basal layer of unit 52 is present on both the limbs and the trough of the fold; all

sublayers appear to thicken towards the center of the fold.

The upper sandy layers of unit 52 are present only in the

center of the fold. A shear zone present in meter 2 indicates

that an event occurred when at least the lower half of 52 was deposited. We interpret that the thickness change is

dominated by younger faulting that juxtaposed thinner uphill (north of fault) units against units that are thicker in the

trough

Minor thickness changes of unit 52 across fault zone. No fault is seen to facilitate the thickness change in this exposure, lowering overall rank. However, the basal unit of 52, a pale green silt, appears only on the thicker side of the unit, suggesting that some accommodation space was produced and filled with this unit. Note that the thickness is about the same as the apparent separation on the fault at meter 6 that cuts the base of 52 . The upper sand unit of 52 is present on the upturned limb, suggesting continued filling of a fold that had a scarp north of the faults that are associated with an event at unit 49

Sandy units at the top of unit 52 are strongly folded, and present only near this fault zone in meter 3 . The presence of these units may reflect an event that caused folding when unit 53 and part of unit 52 were at the ground surface

Unit 52 contains alternating sand and silt layers which thicken into the fold from meters 6 to 11. Faults that continue higher in meters 3 and 11 juxtapose sections of unit 52 that have different thicknesses, further supporting lateral thickness changes in unit 52. No observed faults are attributable to this folding, resulting in a lowering of the event quality 


\begin{tabular}{cccccccccc}
\hline $\begin{array}{c}\text { Likely unit } \\
\text { of event } \\
\text { horizon }\end{array}$ & $\begin{array}{c}\text { Trench } \\
\text { cut } \\
\text { label }\end{array}$ & $\begin{array}{c}\text { Meter } \\
\text { on } \\
\text { cut }\end{array}$ & $\begin{array}{c}\text { Event } \\
\text { evidence } \\
\text { type }\end{array}$ & $\begin{array}{c}\text { Lowest } \\
\text { affected } \\
\text { unit }\end{array}$ & $\begin{array}{c}\text { Highest } \\
\text { affected } \\
\text { unit }\end{array}$ & $\begin{array}{c}\text { Quality } \\
\text { of event } \\
\text { evidence }\end{array}$ & $\begin{array}{c}\text { No. of } \\
\text { observations }\end{array}$ & $\begin{array}{c}\text { Sum of } \\
\text { quality }\end{array}$ \\
\hline 54 & T1E23 & $\begin{array}{c}3,5, \\
7\end{array}$ & fz & 55 & 53 & 5 & 2 & 10 & Fault \\
\hline
\end{tabular}

Faulting in meter 3 and 5 cuts through units 55 and older, producing a graben that is filled with unit 54 . The composition of unit 54 is a green-gray clay where it is deposited in structural lows, but is siltier and an oxidized brown color on structural highs. In the structural low adjacent to the northern fault zone in meter 3 , both types of the unit are present, suggesting that some of unit 54 was in place when an event occurred, or that there was additional mixing during a subsequent event. Removing the folding observed in units 53 and younger, the fault in meter 3 fault would dip about $60^{\circ}$ to the south. On the southern fault (meter 5), faulting offsets the base of unit 54, further supporting an event during the deposition of this unit. The fault in meter 7 also supports this event, although its upward termination is not well resolved. Note that the thick section of unit 54 only present in this exposure could be the fault-bound slice of clay present in T1E21, meter 3

Unit 54 doubles in thickness across a series of faults. Although these faults continue into unit 52, right-lateral motion is consistent with juxtaposition of a thicker unit 54 on the downslope (southern) side of the fault zone. Within this fault zone, a shear zone fabric of alternating thin bands of clays and sands in unit 56 is subparallel to the fault zones (vertical fabric in meter 1 ). Towards the top of the fault zone, the fabric curves to become parallel to the overlying unit 55/54 contact, suggesting that the shearing occurred close to the beginning of the deposition of unit 54, or at the top of unit 55 In meter 1 , a fault with an apparent dip of $45^{\circ}$ to the north juxtaposes sections of unit 54 that differ in thickness by over two times. It is unclear how the fault terminates; unit 53 is not offset here, suggesting that the displacement occurred during the deposition of unit 54 and that no change in the texture of the unit occurred during this event. We do not rate this evidence as high since there is some possibility that this fault, like other faults in this meter, actually continued higher and terminated in distributed deformation of units 52 and younger This seems unlikely, however, as unit 53 is not offset by this lower fault strand and the thickness changes of unit 54 are significant 


\begin{tabular}{ccccccccc}
\hline $\begin{array}{c}\text { Likely unit } \\
\text { of event } \\
\text { horizon }\end{array}$ & $\begin{array}{c}\text { Trench } \\
\text { cut } \\
\text { label }\end{array}$ & $\begin{array}{c}\text { Meter } \\
\text { on } \\
\text { cut }\end{array}$ & $\begin{array}{c}\text { Event } \\
\text { evidence } \\
\text { type }\end{array}$ & $\begin{array}{c}\text { Lowest } \\
\text { affected } \\
\text { unit }\end{array}$ & $\begin{array}{c}\text { Highest } \\
\text { affected } \\
\text { unit }\end{array}$ & $\begin{array}{c}\text { Quality } \\
\text { of event } \\
\text { evidence }\end{array}$ & $\begin{array}{c}\text { No. of } \\
\text { observations }\end{array}$ & $\begin{array}{c}\text { Sum of } \\
\text { quality }\end{array}$ \\
\hline 54 & T1E7 & $0-2$ & tc & 54 & 53 & 1 & 3 & 3
\end{tabular}

$\mathrm{ft}$

56

Fault with apparent dip of $30^{\circ}$ produces $30 \mathrm{~cm}$ of separation across the lower contact of unit 54 and juxtaposes a thin section of unit 54 against one that is three times thicker. This fault continues into unit 53 with less separation. A second fault in these meters produces a similar pattern in unit 54, but the fault is observed to continue through unit 52, indicating it moved in a younger event. This exposure shows that unit 54 has significant lateral thickness variations, whereas unit 53 does not; the cause of the thickness variations in 54 can not be discerned. As each fault in this exposure does deform younger units, it is possible that all of the deformation is produced in a single, younger event, so we rank this evidence as low quality. Two faults in meter 0 show minor displacement of the base of unit 54

Fault with apparent dip of $25^{\circ}$ juxtaposes a thin section of unit 54 against a section that is over three times thicker. Offset reduces up the fault; the separation of the base of unit 54 is about $50 \mathrm{~cm}$ whereas the separation of unit 53 is $\sim 10 \mathrm{~cm}$. Although the fault is associated with younger deformation, it shows that unit 54 has significant lateral thickness variations, but the cause of the variation is unclear due to overprinting, so the quality is ranked as low

Subvertical fault produces $\sim 10 \mathrm{~cm}$ of separation in the base of unit 54 but does not offset the upper contact (the fault terminates in a fracture that continues in unit 52 and is likely offset by younger low-angle fault). Deformation indicates that unit 54 has lateral thickness variations (here more modest than other exposures) but the cause is not clear

Unit 55 is twice as thick in the graben between meter 3 and 5 .

This unit is an organic-rich clay that elsewhere does not show dramatic thickness changes. Although all of the faults bounding this feature continue into younger layers, the thickness change of unit 55 suggests that an event may have occurred early in the deposition of unit 55. The vertical separation of unit 58 on the southernmost fault in meter 3 is equal to the thickness of unit 55, further supporting an event at this horizon 


\begin{tabular}{|c|c|c|c|c|c|c|c|c|c|}
\hline $\begin{array}{l}\text { Likely unit } \\
\text { of event } \\
\text { horizon }\end{array}$ & $\begin{array}{l}\text { Trench } \\
\text { cut } \\
\text { label }\end{array}$ & $\begin{array}{l}\text { Meter } \\
\text { on } \\
\text { cut }\end{array}$ & $\begin{array}{l}\text { Event } \\
\text { evidence } \\
\text { type }\end{array}$ & $\begin{array}{l}\text { Lowest } \\
\text { affected } \\
\text { unit }\end{array}$ & $\begin{array}{l}\text { Highest } \\
\text { affected } \\
\text { unit }\end{array}$ & $\begin{array}{l}\text { Quality } \\
\text { of event } \\
\text { evidence }\end{array}$ & $\begin{array}{c}\text { No. of } \\
\text { observations }\end{array}$ & $\begin{array}{l}\text { Sum of } \\
\text { quality }\end{array}$ & Description and interpretation of event evidence \\
\hline 56 & T1E21 & 7 & $\mathrm{ft}$ & 57 & 55 & 0 & 0 & 0 & $\begin{array}{l}\text { Vertical fault with few centimeters separation of unit 57, may } \\
\text { continue as high as unit 56. At this location, a low-angle fault } \\
\text { (dashed line) crosses the projection of the vertical fault; } \\
\text { neither contact is clear, but the vertical fault may have } \\
\text { continued higher and been subsequently offset by the low- } \\
\text { angle fault. If the last scenario is the case then the upper limit } \\
\text { of faulting is uncertain, as it may have been translated out of } \\
\text { the plane of this exposure }\end{array}$ \\
\hline 57 & T1E5 & $2-6$ & tc & 60 & 55 & 1 & 1 & 1 & $\begin{array}{l}\text { Section between unit } 59 \text { and base of unit } 54 \text { doubles in } \\
\text { thickness across a series of faults that continue up into to } \\
\text { younger layers. This change could reflect juxtaposition of } \\
\text { thinner (uphill) deposits; no causal fault is apparent. This } \\
\text { results in weak evidence for an event, likely around the } \\
\text { deposition of unit 57, as units } 58 \text { and } 59 \text { seem about uniform } \\
\text { in thickness }\end{array}$ \\
\hline$>56$ & T1E21 & 8 & $\mathrm{ft}$ & 57 & 53 & 0 & 1 & 0 & $\begin{array}{l}\text { Fault with } 10 \mathrm{~cm} \text { of vertical separation of units } 57 \text { and older; } \\
\text { low-angle fault cuts off the top of the fault, so upper } \\
\text { boundary is unknown }\end{array}$ \\
\hline NA & T1E20 & $1-3$ & laf & $>35$ & & 0 & 1 & 0 & $\begin{array}{l}\text { Low-angle fault, likely a slide plane for soft-sediment } \\
\text { deformation. This fault cuts faults that are connected to } \\
\text { events in unit } 24 \text {, so it is likely associated with younger } \\
\text { deformation. Motion on this fault could contribute to the } \\
\text { appearance of folding in units } 51-45 \text { in meter } 3\end{array}$ \\
\hline NA & T1E20 & $1-3$ & laf & $>53$ & 53 & 0 & 1 & 0 & $\begin{array}{l}\text { Low-angle fault appears to cut through units } 54 \text { and older and } \\
\text { likely truncates a fault in meter } 7 \text {. Upper limit on the timing } \\
\text { of this deformation feature is not possible based on cross } \\
\text { cutting relationships. Note that a similar fault is present at the } \\
\text { same horizon on north side of trench }\end{array}$ \\
\hline NA & T1E21 & $0-4$ & laf & 57 & 24 & 0 & 1 & 0 & $\begin{array}{l}\text { Low-angle fault is almost bedding parallel, cuts through units } \\
55 \text { and } 58 \text {. It appears to offset faults that continue up to the } \\
\text { fault from an earthquake that occurred during deposition of } \\
\text { unit 24, so the low-angle fault likely postdates the older } \\
\text { section }\end{array}$ \\
\hline NA & T1E21 & $7-9$ & laf & 57 & 24 & 0 & 1 & 0 & $\begin{array}{l}\text { Fault in meter } 8 \text { is truncated by low-angle fault observed } \\
\text { between units } 55 \text { and } 58 \text {. Younger limit of timing of motion } \\
\text { on this feature is not known due to an absence of cross } \\
\text { cutting features }\end{array}$ \\
\hline
\end{tabular}

